1

2

3

4

5

6

9

$7 \quad{ }^{*}$ Corresponding Author: Chun-Xiao Zhang, Tel.: +86 592 6181054; Fax: +86 592 6181054; E-mail:

$8 \quad$ cxzhang@jmu.edu.cn.

\title{
Optimal dietary methionine requirement of bullfrog Rana (Lithobates)
}

catesbeiana

Chun-xiao Zhang ${ }^{1, *}$, Wei Feng ${ }^{1}$, Ling Wang ${ }^{1}$, Kai Song ${ }^{1}$, Kang-le Lu $^{1}$, Peng Li $^{2}$

${ }^{1}$ Xiamen Key Laboratory for Feed Quality Testing and Safety Evaluation, Fisheries College, Jimei

University, Xiamen 361021, China.

${ }^{2}$ National Renderers Association, Alexandra, VA, USA 


\section{Abstract}

A feeding experiment was conducted to determine dietary methionine requirement of bullfrog Rana (Lithobates) catesbeiana. Bullfrogs were fed six experimental diets containing 0.63\%, 1.00\%, $1.42 \%, 1.78 \%, 2.26 \%$ or $2.68 \%$ methionine for 8 weeks. After the feeding experiments, growth performance, body composition, blood biochemistry and expression levels of hepatic genes were determined. The results showed that growth and feed utilization were significantly affected $(P<0.05)$ by dietary methionine levels. Weight gain (WG) and protein efficiency ratio (PER) both increased with increasing level of dietary methionine from $0.63 \%$ to $1.42 \%$ and then decreased. While, the variation trend of feed conversion ratio (FCR) is just opposite with WG and PER. Crude lipid concentrations of whole body and muscle tissue were also significantly affected $(P<0.05)$ by dietary methionine levels. However, there was no significant difference $(P>0.05)$ in amino acid composition in muscle among methionine treatments. Triglyceride (TG) and cholesterol (CHO) levels, as well as aspartate aminotransferase (AST) and alanine aminotransferase (ALT) activities, were all significantly affected $(P<0.05)$ by dietary methionine levels. TG and $\mathrm{CHO}$ levels decreased as dietary methionine increased from $0.63 \%$ to $1.78 \%$ and then increased with further increases in methionine. Serum AST and ALT activities in bullfrogs fed with $0.63 \%$ methionine diet were both significantly higher $(P<0.05)$ than in bullfrogs fed other diets. Gene expressions in bullfrogs fed with $1.00 \%, 1.42 \%$ and $1.78 \%$ methionine diets was higher $(P<0.05)$ than these of other groups. On the basis of WG and PER, the optimal level of dietary methionine for bullfrogs was estimated to be between $1.53 \%$ and $1.62 \%$ of diet using second-order polynomial regression analysis. The corresponding optimal level of total sulfur amino acids in the diet of bullfrogs is therefore between $1.79 \%$ and $1.88 \%$ of diet in the presence of $0.26 \%$ cystine.

Keywords: Bullfrog Rana (Lithobates) catesbeiana, methionine requirement, feed utilization, body 
composition

\section{Introduction}

Protein is the most expensive item in aquafeeds, and fish meal is the major protein source in such feeds (Moreira et al., 2008). However, while the demand for fish meal in aquafeeds is continually increasing, the annual global supply of fish meal has remained relatively constant through time and has even decreased in recent years. The limited supply and high cost of fish meal have forced the industry to investigate alternative protein sources for use in feeds, such as soybean meal and other plant-derived protein sources (Kumar et al., 2014). However, it is important to consider the balance of essential amino acids (EAAs) when incorporating protein ingredients in the formulation of aquafeeds. Methionine takes part in protein synthesis and other important physiological functions and is essential for normal animal growth (Nguyen and Davis, 2009). Methionine is often the most limiting amino acid in soy protein sources used in place of fish meal (Sardar et al., 2009). Methionine deficiency often results in slow growth and poor feed efficiency in cultured animals (Opstvedt et al., 2003) and can cause bilateral cataracts in fish (Barash et al., 1982). Therefore, it is very important to determine the level of methionine required for normal growth and feed utilization of cultured animals.

The bullfrog Rana (Lithobates) catesbeiana is native to North America and was introduced to China in the 1950s (Zhang et al., 2015). Bullfrog meat is a delicacy in many countries and worldwide consumption of bullfrog is increasing (Pasteris et al., 2006). Moreover, other bullfrog body parts such as the liver, gut and skin are used in other industries. Bullfrogs are now commercially reared in frog farms in southeastern China owing to their tender meat, fast growth, adaptability to environmental conditions, efficient feed conversion and high market value (Huang et al., 2014). In 2013, the production of bullfrogs in China was estimated to be 150, 000 tons (Zhang et al., 2015). Therefore, it is important to study the nutritional requirements and optimal feed formulation for bullfrogs. 

recent years, replacement of fish meal in aquafeeds by other protein sources has received heightened

attention. Because methionine is the most limiting amino acid in soy protein sources (Sardar et al., 2009), it is necessary to determine the methionine level required for growth of bullfrogs. This study was designed to evaluate the effect of dietary methionine levels on growth and body composition of bullfrogs. The results will aid the development of economical high-quality artificial feed for bullfrogs.

\section{Materials and methods}

\subsection{Experimental diets}

Six iso-nitrogenous and iso-lipidic diets were formulated with fish meal, soybean protein isolate and soybean meal as the main protein sources; fish oil, soybean oil and soybean lecithin as lipid sources and wheat flour as the carbohydrate source. The diets differed only in DL-methionine and glutamic acid concentrations. The final levels of methionine were confirmed by amino acid analysis to be $0.63 \%, 1.00 \%, 1.42 \%, 1.78 \%, 2.26 \%$ and $2.68 \%$. Formulation and the proximate composition of the experimental diets are presented in Table 1. Moreover, amino acid composition of each experimental diet was presented in Table 2 .

Prior to preparing the diets, the feed ingredients were ground and passed through a $250-\mu \mathrm{m}$ sieve. The dry ingredients of each diet were mixed thoroughly in a mixer before the oil mix (fish oil:soybean oil:soybean lecithin $=2: 2: 1.5$ ) was added. After the oil mix had dispersed, water was added and the ingredients were again mixed. Then the mixture was transferred into an MY45 single screw extrusion machine (Xiamen Fishing Machinery Feed Machinery Co., Xiamen, China) to produce neutrally buoyant $4.0 \times 5.5-\mathrm{mm}$ pellets. The pellets were dried to a moisture content of approximately $10 \%$ in a 
forced-air environment at $20^{\circ} \mathrm{C}$ for approximately $20 \mathrm{~h}$, and then stored at $-20{ }^{\circ} \mathrm{C}$ until used.

2.2 Experimental bullfrogs and feeding trial

Bullfrogs were obtained from a commercial farm (Xiamen, China). Prior to the start of the experiment, bullfrogs were reared in an indoor aquarium $(150 \times 70 \times 60 \mathrm{~cm})$ and fed a commercial diet for 15 days to acclimate to the experimental conditions. After the acclimation period, bullfrogs (initial body weight: $40.01 \pm 0.24 \mathrm{~g})$ were randomly sorted into 18 aquaria $(70 \times 40 \times 40 \mathrm{~cm})$ with an average water depth of $4 \mathrm{~cm}$. Each aquarium was stocked with 14 bullfrogs. An additional nine bullfrogs were randomly collected for analysis of initial whole-body composition. During the experimental period, bullfrogs were hand-fed to apparent satiation twice daily (8:00 and 18:00 h). Each diet was tested in three aquaria, and the trial lasted 8 weeks. Bullfrogs were held under indoor natural photoperiod conditions $(12 \mathrm{D} / 12 \mathrm{~L})$ and at $24-30{ }^{\circ} \mathrm{C}$ throughout the feeding trial.

\subsection{Sample collection and analysis methods}

\subsubsection{Sample collection}

At the end of the feeding trial, bullfrogs were starved for $24 \mathrm{~h}$ prior to sampling. The total number and weight of bullfrogs in each aquarium were determined and five bullfrogs per aquarium were randomly collected. Two bullfrogs were randomly sampled for analysis of whole body composition and the remaining three bullfrogs were collected for blood, liver and muscle tissue samples. Blood samples were rapidly centrifuged $\left(850 \times \mathrm{g}, 10 \mathrm{~min}, 4^{\circ} \mathrm{C}\right)$ and the serum was stored at $-80{ }^{\circ} \mathrm{C}$ until analysis.

\subsubsection{Proximate analysis}

Feeds, whole bodies and muscle tissues were analyzed similarly for their proximate compositions.

Moisture was determined by oven drying at $105{ }^{\circ} \mathrm{C}$ until a constant weight was reached. Crude protein content (nitrogen $\times 6.25$ ) was measured using an Auto Kjeldahl System (FOSS Kjeltec 8400, Switzerland), crude lipid by ether-extraction and ash by incineration at $550{ }^{\circ} \mathrm{C}$ for $4 \mathrm{~h}$. The amino acid 
101

compositions of experimental diets and muscle tissues were carried out using an automatic amino acid analyzer (Hitachi L-8900, Tokyo, Japan) after hydrolysis in $6 \mathrm{~N} \mathrm{HCl}$ for $22 \mathrm{~h}$ at $110{ }^{\circ} \mathrm{C}$.

\subsubsection{Measurements of serum biochemical parameters}

Serum concentrations of triglyceride (TG) and cholesterol (CHO) were determined by colorimetric enzymatic methods using commercial kits (Beijing BHKT Clinical Reagent Co., Beijing, China). Plasma aspartate aminotransferase (AST) and alanine aminotransferase (ALT) enzymatic activities were measured by enzymatic colorimetric methods, as described in Lu et al. (2013).

\subsubsection{Total RNA extraction, reverse transcription and real-time PCR}

Total RNA was extracted from liver tissues using RNAiso Plus (Takara Co. Ltd, Japan). To avoid genomic DNA amplification, RNA samples were first treated by RQ1 RNase-free DNase prior to reverse transcription-PCR (Takara Co. Ltd, Japan). Complementary DNA (cDNA) was generated from 500 ng of DNase-treated RNA using the ExScript RT-PCR Kit (Takara Co. Ltd, Japan). The mixture consisted of $500 \mathrm{ng}$ of RNA, $2 \mu \mathrm{L}$ of buffer $(5 \times), 0.5 \mu \mathrm{L}$ of a deoxynucleotide triphosphate mixture (10 $\mathrm{mM}$ each), $0.25 \mu \mathrm{L}$ of RNase inhibitor $(40 \mathrm{U} / \mu \mathrm{L}), 0.5 \mu \mathrm{L}$ of dT-AP primer $(50 \mathrm{mM}), 0.25 \mu \mathrm{L}$ of ExScript RTase (200 U/ $\mu \mathrm{L})$, and diethylpyrocarbonate-treated $\mathrm{H}_{2} \mathrm{O}$, with a total volume of $10 \mu \mathrm{L}$. The reaction conditions were $42{ }^{\circ} \mathrm{C}$ for $40 \mathrm{~min}, 90{ }^{\circ} \mathrm{C}$ for $2 \mathrm{~min}$, and $4{ }^{\circ} \mathrm{C}$ thereafter.

Real-time PCR was employed to determine mRNA levels based on the SYBR® Green I fluorescence kit (Takara Co. Ltd, Japan). Primer characteristics used for real-time PCR are listed in Table 3. Real-time PCR was performed in a Mini Option real-time detector (BIO-RAD, Hercules, CA, USA). The fluorescent quantitative PCR reaction solution consisted of $12.5 \mu 1$ SYBR® premix Ex $\operatorname{Taq}^{\mathrm{TM}}(2 \times), 0.5 \mu \mathrm{l}$ PCR forward primer $(10 \mu \mathrm{M}), 0.5 \mu \mathrm{L}$ PCR reverse primer $(10 \mu \mathrm{M}), 2.0 \mu \mathrm{L}$ RT reaction (cDNA solution), and $9.5 \mu \mathrm{L} \mathrm{dH_{2 }} \mathrm{O}$. The reaction conditions were as follows: $95{ }^{\circ} \mathrm{C}$ for $3 \mathrm{~min}$ 
123

followed by 45 cycles consisting of $95{ }^{\circ} \mathrm{C}$ for $10 \mathrm{~s}$ and $60{ }^{\circ} \mathrm{C}$ for $20 \mathrm{~s}$. At the conclusion of the 45 cycles, the fluorescent flux was recorded and the reaction continued at $72{ }^{\circ} \mathrm{C}$ for $3 \mathrm{~min}$. The dissociation rate was then measured by increasing the temperature from 65 to $90{ }^{\circ} \mathrm{C}$. Each increase of $0.2{ }^{\circ} \mathrm{C}$ was maintained for $1 \mathrm{~s}$ and the fluorescent flux was recorded. All amplicons were initially separated by agarose gel electrophoresis to ensure that they were of the correct size. A dissociation curve was determined during the PCR program to make sure that specific products were obtained in each run. Following the reaction, the fluorescent data were converted into $\mathrm{Ct}$ values. Each transcript level was normalized to $\beta$-actin using the $2^{-\Delta \Delta \mathrm{CT}}$ method.

\subsection{Statistical analysis}

All data were pooled within each replicate and analyzed using one-way analysis of variance and Tukey's multiple range tests. Data presented are means of the three replicate aquaria. The level of significance was set at $P<0.05$. Analyses were performed using SPSS version 17.0 (SPSS Inc., Chicago, IL, USA). The optimum dietary methionine level was estimated using second-order polynomial regression analysis, one with the response variable as weight gain and the other with the response variable of protein efficiency ratio.

\section{Results}

\subsection{Growth performance}

After the 8-week feeding trial, survival of bullfrogs was above $90 \%$ for all replicates and showed little difference among the treatment levels $(P>0.05$, Table 4). Weight gain (WG) of bullfrogs was significantly affected $(P<0.05)$ by dietary methionine levels (Table 4$)$. WG increased as dietary methionine levels increased from $0.63 \%$ to $1.42 \%$, and then decreased. Based on the second-order polynomial regression of WG $v s$. dietary methionine level, the optimal dietary methionine level for 
145

bullfrogs was $1.62 \%$ of the dry diet or $4.01 \%$ of dietary protein (Fig. 1). Feed conversion ratio (FCR) and protein efficiency ratio (PER) were also significantly affected $(P<0.05)$ by dietary methionine levels (Table 4). Based on the second-order polynomial regression analysis of PER vs. dietary methionine level, the optimal dietary methionine level for bullfrogs was $1.53 \%$ of the dry diet or $3.81 \%$ of dietary protein (Fig. 2).

\section{Table 4, Fig. 1 and Fig. 2 here}

\subsection{Body composition}

There were no significant differences $(P>0.05)$ among groups in moisture, crude protein or ash of whole body and muscle (Table 5). Crude lipid of whole body and muscle were significantly affected $(P<0.05)$ by dietary methionine levels (Table 5$)$. Seventeen amino acids were isolated from the muscle including nine essential amino acids (EAA) and eight non-essential amino acids (NEAA) (Table 6). There were no significant differences $(P>0.05)$ among groups in their concentrations of total amino acids, EAAs or NEAA.

\section{Table 5 \& 6 here}

\subsection{Blood biochemistry}

The TG and CHO levels, as well as serum AST and ALT activities, were significantly affected $(P<0.05)$ by dietary methionine levels (Table 7$)$. TG and CHO levels decreased as dietary methionine levels increased from $0.63 \%$ to $1.78 \%$ and then increased with further increases in dietary methionine. Both AST and ALT serum activities of bullfrogs fed diets with $0.63 \%$ methionine (the lowest concentration) were significantly higher $(P<0.05)$ than those of other groups.

\section{Table 7 here}

3.4 Expression levels of hepatic genes 
Gene expression of IGF-I and IGF-IR in liver tissue was significantly affected $(P<0.05)$ by dietary methionine levels (Fig. 3). Expression in bullfrogs fed with $1.00 \%, 1.42 \%$ and $1.78 \%$ methionine diets was significantly higher $(P<0.05)$ than that in other groups (Fig. 3$)$.

\section{Fig. 3 here}

\section{Discussion}

Methionine is an essential amino acid required by all animals, and plays an important role in protein synthesis and stimulating the growth of aquatic animals. Dose-response experiments with increasing concentrations of a specific amino acid are accepted in principle as a method for determining the dietary requirement for that amino acid (Cowey, 1995). The results here showed that weight gain increased as dietary methionine levels increased from $0.63 \%$ to $1.42 \%$, and then decreased.

This indicated that bullfrogs are able to utilize the crystalline form of methionine. In this study, based on the second-order polynomial regression analysis of WG vs. dietary methionine level, the optimal dietary methionine concentration for bullfrogs was $1.62 \%$ of total diet or $4.01 \%$ of dietary protein. Moreover, PER of bullfrogs fed with $1.00 \%, 1.42 \%$ and $1.78 \%$ methionine diets were significantly higher than those of other groups. Based on the second-order polynomial regression analysis of PER vs. dietary methionine level, the optimal dietary methionine concentration for bullfrogs was $1.53 \%$ of diet or $3.81 \%$ of dietary protein. Previous studies have determined the methionine requirements of fish species to be within the range of $0.8 \%-1.44 \%$ of total diet or $1.8 \%-4.0 \%$ of dietary protein (Mai et al., 2006; Niu et al., 2013; Liao et al., 2014). Compared with requirements for these species, the optimal dietary methionine amount for bullfrogs was higher. The discrepancies observed in the methionine requirement may be attributable to the differences between species. Bullfrogs had the very lower FCR (<1), compared to other cultured animals such as softshell turtle and fish species (Huang et al., 2002; 
189

Mai et al., 2006; Niu et al., 2013; Liao et al., 2014). The high feed utilization may also account for the higher requirement of methionine of bullfrog. Besides, some other factors such as size, feed ingredients, palatability, feeding regime and environmental conditions could also affect measured amino acid requirements (Mai et al., 2006). In addition, the presence of cystine in the diet can reduce the level of methionine needed for maximum growth for juvenile golden pompano Trachinotus ovatus (Niu et al., 2013). Cystine can replace about $40 \%$ of dietary methionine in fish (Kim et al., 1992; Griffin et al., 1994; Twibell and Wilson, 2000; Goffa and Iiia, 2004). This suggests that there may be a total sulfur amino acid requirement for animals rather than a specific methionine requirement (Wilson, 1986). In this study, the optimal total sulfur amino acid concentration for bullfrogs based on WG or PER was measured to be $1.88 \%$ or $1.79 \%$ of total diet and $4.65 \%$ or $4.43 \%$ of dietary protein, respectively, using the second-order polynomial regression analysis.

Methionine deficiency causes poor growth of bullfrogs, although no overt signs of deficiency were observed in this study. Methionine plays many metabolic functions, acting as a component of protein synthesis, a sulfur source for synthesis of other sulfur-containing biochemicals and a methyl group donor for methylation reactions (Buono et al., 2002; Espe et al., 2008). In addition, methionine plays a role in lipid metabolism (Brosnan and Brosnan, 2006). Therefore, methionine deficiency would surely suppress the growth of cultured animals (Griffin et al., 1994; Mai et al., 2006; Liao et al., 2014). Conversely, excessive dietary methionine may be toxic to bullfrogs or may lead to reduced growth according the results of this study. Some studies suggest that excessive methionine could accumulate and oxidize to ketones, which would induce production of toxic metabolites and reduce growth (Murthy and Varghese, 1998; Shusaku et al., 2001). Elevated AST activities in the blood of bullfrog fed with high-methionine diets also confirmed the liver damage. In addition, excessive methionine intake 
could affect the absorption and utilization of other amino acids because there is a common carrier for the uptake and transport of methionine and other neutral amino acids in the intestines (Bogé et al., 2002). If excess methionine limits the uptake of other essential amino acids, this could result in poor growth at high methionine concentrations.

Methionine is the precursor of S-adenosyl methionine, which is a substrate for de novo synthesis of choline (Chawla et al., 1998). Adequate methionine in the diet of an animal promotes choline and carnitine synthesis in the liver, which provides phospholipids and acetyl-CoA for cholesterol and lipoprotein synthesis (Wang et al., 2015). Therefore, methionine is useful for lipid metabolism. Plasma TG and CHO levels are important metrics of lipid metabolism. In this study, TG and CHO levels in the serum of bullfrogs fed diets with 1.42-1.78\% supplementation were lower than those of other groups, suggesting the vigorous metabolism of lipid. Another symptom of methionine deficiency for animals is the development of fatty liver tissue, which can be detrimental for the general health of farmed aquatic animals (Espe et al., 2010). In previous studies, fish given a sub-optimal methionine diet showed fatty acid synthase activity that was approximately six times higher than in fish fed a diet with adequate methionine, indicating higher de novo lipogenesis (Espe et al., 2010). Similarly, in the present study, a lower level of dietary methionine resulted in significantly higher TG concentrations.

Insulin-like growth factor-I (IGF-I) is a hormone that plays an important role in the regulation of whole-body protein synthesis. It has been proposed as a mediator of the effects of nutrient supply on growth (Stubbs et al., 2002). Dietary restriction of proteins or essential amino acids has been shown to reduce IGF-I level in the study of Takenaka et al. (2000). In the current study, IGF-I expression in liver tissues of bullfrogs fed the low-methionine diet $(0.63 \%)$ was significantly lower than that of groups fed the $1.00 \%, 1.42 \%$ and $1.78 \%$ methionine diets. We also showed that changes in IGF-I expression have 
a close relationship with the growth rate of bullfrogs. In particular, increased methionine levels appeared to decrease expression of IGF-I, which may be the result of a negative feedback loop in the production of growth hormones.

In conclusion, the optimal concentration of dietary methionine for bullfrogs was estimated to be $1.53 \%$ or $1.62 \%$ of diet based on weight gain or protein efficiency ratio, respectively. Further, in the presence of $0.26 \%$ cystine, the optimal level of total sulfur amino acid for bullfrogs was either $1.79 \%$ or $1.88 \%$ of diet. Dietary methionine concentration appears to have a close relationship with hepatic IGF-I expression.

\section{Acknowledgements}

This work was funded by the National Natural Science Foundation of China (Grant No. 31572625), the Special Fund for Agro-scientific Research in the Public Interest (201303053) and the USDA Market Access Program. We thank Xiamen Yinhao Feed Co., Ltd. and Fuxing (Xiamen)

Organic Feed Co., Ltd. for donating feed ingredients. We would like also to thank Wei-dong Fang for his contribution to the analyses.

\section{References}

Barash, H., Poston, H.A., Rumsey, G.L., 1982. Differentiation of soluble proteins in cataracts caused by deficiencies of methionine, riboflavin or zinc in diets fed to Atlantic salmon, Salmo salar, rainbow trout, Salmo gairdneri, and lake trout, Salvelinus namaycush. Cornell Vet. 72, 361-371.

Bogé, G., Roche, H., Balocco, C., 2002. Amino acid transport by intestinal brush border vesicles of a marine fish, Boops salpa. Comp. Biochem. Phys. B 131, 19-26.

Brosnan, J.T., Brosnan, M.E., 2006. The sulfur-containing amino acids: an overview. J. Nutr. 136, 1636S-1640S.

Buono, M., Di, Wykes, L.J., Ball, R.O., Pencharz, P.B., 2002. Dietary cysteine reduces the methionine requirement in men. Am. J. Clin. Nutr. 74, 761-766.

Carmona-Osalde, C., Olvera-Novoa, M.A., Rodríguez-Serna, M., Flores-Nava, A., 1996. Estimation of the protein requirement for bullfrog (Rana catesbeiana) tadpoles, and its effect on metamorphosis ratio. Aquaculture 141, 223-231.

Chawla, R.K., Watson, W.H., Eastin, C.E., Lee, E.Y., Schmidt, J., Mcclain, C.J., 1998. S-adenosylmethionine deficiency and TNF-alpha in lipopolysaccharide-induced hepatic injury. 
Am. J. Phys. 275, 125-129.

Cowey, C.B., 1995. Protein and amino acid requirements: A critique of methods. J. Appl. Ichthyol. 11, 199-204.

Espe, M., Hevrøy, E.M., Liaset, B., Lemme, A., El-Mowafi, A., 2008. Methionine intake affect hepatic sulfur metabolism in Atlantic salmon, Salmo salar. Aquaculture 274, 132-141.

Espe, M., Rathore, R.M., Du, Z.Y., Liaset, B., El-Mowafi, A., 2010. Methionine limitation results in increased hepatic FAS activity, higher liver 18:1 to 18:0 fatty acid ratio and hepatic TAG accumulation in Atlantic salmon, Salmo salar. Amino Acids 39, 449-460.

Goffa, J.B., Iiia, D.M.G., 2004. Evaluation of different sulfur amino acid compounds in the diet of red drum, Sciaenops ocellatus, and sparing value of cystine for methionine. Aquaculture 241, 465-477.

Griffin, M.E., White, M.R., Brown, P.B., 1994. Total sulfur amino acid requirement and cysteine replacement value for juvenile hybrid striped bass (Morone saxatilis $\times$ M. chrysops). Comp. Biochem. Phys. A 108, 423-429.

Huang C.H., Lin W.Y., 2002. Estimation of optimal dietary methionine requirement for softshell turtle, Pelodiscus sinensis. Aquaculture 207, 281-287.

Huang K.K., Zhang C.X., Wang L., Song K., Huang F., 2014. Effects of dietary protein and lipid levels on growth of bullfrog Rana catesbeiana. J. Fish. 6, 877-887 (Chinese with English abstract).

Kim, K.I., Kayes, T.B., Amundson, C.H., 1992. Requirements for sulfur amino acids and utilization of D-methionine by rainbow trout (Oncorhynchus mykiss). Aquaculture 101, 95-103.

Kumar, B.P., Ramudu, K.R., Devi, B.C., 2014. Mini review on Incorporation of Cotton Seed Meal, an Alternative to Fish Meal in Aquaculture Feeds. Inter. J. Biolog. Res. 2, 99-105.

Liao, Y.J., Ren, M.C., Liu, B., Sun, S.M., Cui, H.H., Xie, J., Zhou, Q.L., Pan, L.K., Chen, R.L., Ge, X.P., 2014. Dietary methionine requirement of juvenile blunt snout bream (Megalobrama amblycephala) at a constant dietary cystine level. Aquac. Nutr. 20, 741-752.

Lu, K.L., Xu, W.N., Li, J.Y., Li, X.F., Huang, G.Q., Liu, W.B., 2013. Alterations of liver histology and blood biochemistry in blunt snout bream Megalobrama amblycephala, fed high-fat diets. Fish. Sci. 79, 661-671.

Mai, K., Wan, J., Ai, Q., Xu, W., Liufu, Z., Zhang, L., Zhang, C., Li, H., 2006. Dietary methionine requirement of large yellow croaker, Pseudosciaena crocea $R$. Aquaculture 253, 564-572.

Moreira, I.S., Peres, H., Couto, A., Enes, P., Oliva-Teles, A., 2008. Temperature and dietary carbohydrate level effects on performance and metabolic utilisation of diets in European sea bass (Dicentrarchus labrax) juveniles. Aquaculture 274, 153-160.

Murthy, R.K., Varghese, T.J., 1998. Total sulphur amino acid requirement of the Indian major carp, Labeo rohita (Hamilton). Aquac. Nutr. 4, 61-65.

Nguyen, T.N., Davis, D.A., 2009. Re-evaluation of total sulphur amino acid requirement and determination of replacement value of cystine for methionine in semi-purified diets of juvenile Nile tilapia, Oreochromis niloticus. Aquac. Nutr. 15, 247-253.

Niu, J., Du, Q., Lin, H.Z., Cheng, Y.Q., Huang, Z., Wang, Y., Wang, J., Chen, Y.F., 2013. Quantitative dietary methionine requirement of juvenile golden pompano Trachinotus ovatus at a constant dietary cystine level. Aquac. Nutr. 19, 677-686.

Olvera-Novoa, M.A., Ontiveros-Escutia, V.M., Flores-Nava, A., 2007. Optimum protein level for growth in juvenile bullfrog (Rana catesbeiana Shaw, 1802). Aquaculture 266, 191-199.

Opstvedt, J., Aksnes, A., Hope, B., Pike, I.H., 2003. Efficiency of feed utilization in Atlantic salmon 
(Salmo salar L.) fed diets with increasing substitution of fish meal with vegetable proteins. Aquaculture 221, 365-379.

Pasteris, S.E., Bühler, M.I., Nader-Macías, M.E., 2006. Microbiological and histological studies of farmed-bullfrog (Rana catesbeiana) tissues displaying red-leg syndrome. Aquaculture 251, 11-18.

Sardar, P., Abid, M., Randhawa, H.S., Prabhakar, S.K., 2009. Effect of dietary lysine and methionine supplementation on growth, nutrient utilization, carcass compositions and haemato-biochemical status in Indian Major Carp, Rohu (Labeo rohita H.) fed soy protein-based diet. Aquac. Nutr. 15, 339-346.

Shusaku T., Shimeno, S., Hosokawa, H., Ukawa, M., 2001. Effect of lysine and methionine supplementation to a soy protein concentrate diet for red sea bream Pagrus major. Fish. Sci. 67, 1088-1096.

Stubbs, A.K., Wheelhouse, N.M., Lomax, M.A., Hazlerigg, D.G., 2002. Nutrient-hormone interaction in the ovine liver: methionine supply selectively modulates growth hormone-induced IGF-I gene expression. J. Endocrinol. 174, 335-341.

Takenaka, A., Oki, N., Takahashi, S.I., Noguchi, T., 2000. Dietary restriction of single essential amino acids reduces plasma insulin-like growth factor-I (IGF-I) but does not affect plasma IGF-binding protein-1 in rats. J. Nutr. 130, 2910-2914.

Twibell, R., Wilson, K., Pb, 2000. Dietary sulfur amino acid requirement of juvenile yellow perch fed the maximum cystine replacement value for methionine. J. Nutr. 130, 612-616.

Wang, X., Xue, M., Figueiredo-Silva, C., Wang, J., Zheng, Y., Wu, X., Han, F., Mai, K., 2015. Dietary methionine requirement of the pre-adult gibel carp (Carassius auratus gibeilo) at a constant dietary cystine level. Aquac. Nutr. 22, 509-516.

Wilson, R.P., 1986. Protein and amino acid requirements of fishes. Annu. Rev. Nutr. 6, 27-48.

Zhang, C.X., Huang, K.K., Wang, L., Song, K., Zhang, L., Li, P., 2015. Apparent digestibility coefficients and amino acid availability of common protein ingredients in the diets of bullfrog, Rana (Lithobates) catesbeiana. Aquaculture 437, 38-45.

\section{Figure captions}

Fig. 1. Second-order regression analysis between weight gain rate and dietary methionine levels for bullfrog.

Fig. 2. Second-order regression analysis between protein efficiency ratio and dietary methionine levels for bullfrog.

Fig. 3. Relative gene expressions of hepatic IGF-I and IGF-IR in bullfrog fed with different dietary methionine levels. Mean values and standard error (S.E.M.) are present for each parameter $(n=3)$. The values of the expression of the target genes are presented as relative to value of $0.63 \%$ methionine group (set to 1 ). Data were normalized by $\beta$-actin. The values in bar with different letter indicate significant difference $(P<0.05)$. IGF-I: Insulin-like growth factor I; IGF-IR: Insulin-like growth factor I receptor. 
Table 1. Formulation and proximate composition of the experimental diets ( $\%$ dry-matter basis).

\begin{tabular}{|c|c|c|c|c|c|c|}
\hline \multirow[t]{2}{*}{ Ingredients (\%) } & \multicolumn{6}{|c|}{ Methionine levels (\%) } \\
\hline & 0.63 & 1.00 & 1.42 & 1.78 & 2.26 & 2.68 \\
\hline Fish meal & 8.00 & 8.00 & 8.00 & 8.00 & 8.00 & 8.00 \\
\hline Soybean meal & 41.00 & 41.00 & 41.00 & 41.00 & 41.00 & 41.00 \\
\hline Soybean protein isolate & 15.00 & 15.00 & 15.00 & 15.00 & 15.00 & 15.00 \\
\hline Wheat flour & 26.25 & 26.25 & 26.25 & 26.25 & 26.25 & 26.25 \\
\hline Mix oil ${ }^{1}$ & 5.50 & 5.50 & 5.50 & 5.50 & 5.50 & 5.50 \\
\hline Calcium biphosphate & 1.00 & 1.00 & 1.00 & 1.00 & 1.00 & 1.00 \\
\hline Premix ${ }^{2}$ & 0.60 & 0.60 & 0.60 & 0.60 & 0.60 & 0.60 \\
\hline Choline chloride & 0.50 & 0.50 & 0.50 & 0.50 & 0.50 & 0.50 \\
\hline DL-methionine & 0.00 & 0.40 & 0.80 & 1.20 & 1.60 & 2.00 \\
\hline Glutamic acid & 2.00 & 1.60 & 1.20 & 0.80 & 0.40 & 0.00 \\
\hline Others $^{3}$ & 0.15 & 0.15 & 0.15 & 0.15 & 0.15 & 0.15 \\
\hline \multicolumn{7}{|c|}{ Proximate composition (\%) } \\
\hline Methionine & 0.63 & 1.00 & 1.42 & 1.78 & 2.26 & 2.68 \\
\hline Moisture & 7.65 & 8.83 & 8.59 & 8.54 & 8.47 & 8.00 \\
\hline Crude protein & 40.40 & 40.40 & 40.20 & 40.60 & 40.70 & 40.30 \\
\hline Crude lipid & 5.96 & 5.95 & 5.94 & 6.21 & 6.12 & 6.19 \\
\hline Crude ash & 6.90 & 6.65 & 6.63 & 6.62 & 6.68 & 6.79 \\
\hline
\end{tabular}

Notes: ${ }^{1}$ Mix oil: fish oil: soybean oil: soybean lecithin $=2: 2: 1.5$.

${ }^{2}$ Premix supplied the following minerals (mg or g/ kg diet) and vitamins mg or g/ kg diet): NaF, $2 \mathrm{mg} ; \mathrm{KI}, 0.8 \mathrm{mg} ; \mathrm{CoCl}_{2} \cdot 6 \mathrm{H}_{2} \mathrm{O}(1 \%)$, 50mg; $\mathrm{CuSO}_{4} \cdot 5 \mathrm{H}_{2} \mathrm{O}, 10 \mathrm{mg} ; \mathrm{FeSO}_{4} \cdot \mathrm{H}_{2} \mathrm{O}, 80 \mathrm{mg} ; \mathrm{ZnSO}_{4} \cdot \mathrm{H}_{2} \mathrm{O}, 50 \mathrm{mg} ; \mathrm{MnSO}_{4} \cdot \mathrm{H}_{2} \mathrm{O}, 25 \mathrm{mg} ; \mathrm{MgSO}_{4} \cdot 7 \mathrm{H}_{2} \mathrm{O}, 200 \mathrm{mg} ; \mathrm{Zoelite}, 4.55 \mathrm{~g} ;$ thiamin, 10mg; riboflavin, 8mg; pyridoxine $\mathrm{HCl}, 10 \mathrm{mg}$; vitamin $\mathrm{B} 12,0.03 \mathrm{mg}$, vitamin $\mathrm{K} 3,10 \mathrm{mg}$; inositol, 100mg; pantothenic acid, 20mg; niacin acid, 50mg; folic acid, 2mg; biotin, 0.2mg; retinol acetate, 400mg; cholecalciferol, 5mg; alpha-tocopherol, 100mg; ethoxyquin, 150mg; wheat middling, $1.135 \mathrm{~g}$.

${ }^{3}$ Others containing Mold inhibitor, Ethoxyquin and L-ascorbate-2-phosphate (1:1:1). 
Table 2. Amino acid composition of the experimental diets (\% dry-matter basis).

\begin{tabular}{|c|c|c|c|c|c|c|}
\hline \multirow[t]{2}{*}{ Amino acids } & \multicolumn{6}{|c|}{ Methionine levels (\%) } \\
\hline & 0.63 & 1.00 & 1.42 & 1.78 & 2.26 & 2.68 \\
\hline \multicolumn{7}{|l|}{ EAA } \\
\hline $\operatorname{Arg}$ & 3.18 & 3.18 & 3.18 & 3.08 & 3.26 & 3.18 \\
\hline His & 1.20 & 1.17 & 1.19 & 1.16 & 1.22 & 1.21 \\
\hline Ile & 1.70 & 1.62 & 1.66 & 1.59 & 1.66 & 1.61 \\
\hline Leu & 4.56 & 4.40 & 4.41 & 4.21 & 4.53 & 4.51 \\
\hline Lys & 2.96 & 2.92 & 2.95 & 2.91 & 3.10 & 3.05 \\
\hline Met & 0.63 & 1.00 & 1.42 & 1.78 & 2.26 & 2.68 \\
\hline Phe & 2.20 & 2.22 & 2.23 & 2.19 & 2.27 & 2.17 \\
\hline Thr & 1.82 & 1.71 & 1.75 & 1.73 & 1.85 & 1.77 \\
\hline Val & 1.84 & 1.77 & 1.83 & 1.85 & 1.85 & 1.78 \\
\hline \multicolumn{7}{|l|}{ NEAA } \\
\hline Ala & 3.27 & 2.86 & 2.67 & 2.18 & 2.91 & 3.37 \\
\hline Asp & 5.35 & 5.08 & 5.17 & 4.80 & 5.32 & 5.35 \\
\hline Cys & 0.26 & 0.29 & 0.26 & 0.27 & 0.26 & 0.27 \\
\hline Glu & 13.29 & 12.01 & 11.67 & 11.38 & 11.08 & 10.43 \\
\hline Gly & 2.21 & 2.18 & 2.11 & 2.18 & 2.29 & 2.18 \\
\hline Pro & 2.48 & 2.39 & 2.44 & 2.26 & 2.50 & 2.52 \\
\hline Ser & 2.65 & 2.50 & 2.55 & 2.60 & 2.79 & 2.63 \\
\hline Tyr & 1.01 & 1.02 & 1.01 & 0.95 & 0.97 & 0.97 \\
\hline
\end{tabular}


Table 3. Nucleotide sequences of the primers used to assay gene expression by real-time PCR.

\begin{tabular}{llll}
\hline Target gene & Nucleotide sequence 5' -3, & Accession number & Annealing temperature \\
\hline \multirow{2}{*}{ IGF-I } & F: CTACTCACTCTAACCCACTCAGCA & KF819506 & $60^{\circ} \mathrm{C}$ \\
& R: AGCCTCTGTCTCCACATACAAAC & & \\
IGF-IR & F: TCCGTCTGTTAGGCGTTGT & KF819507 & $60^{\circ} \mathrm{C}$ \\
& R: AGGGTTGTTCTCGGCATCT & & \\
$\beta$-actin & F: CATCCTTCTTGGGTATGGAATCA & AB094353 & $60^{\circ} \mathrm{C}$ \\
\hline
\end{tabular}

IGF-I: Insulin-like growth factor I; IGF-IR: Insulin-like growth factor I receptor. 
Table 4. Growth performance of bullfrog fed with different experimental diets.

\begin{tabular}{|c|c|c|c|c|c|c|}
\hline \multirow{2}{*}{$\begin{array}{l}\text { Growth } \\
\text { performance }\end{array}$} & \multicolumn{6}{|c|}{ Methionine levels (\%) } \\
\hline & 0.63 & 1.00 & 1.42 & 1.78 & 2.26 & 2.68 \\
\hline Initial weight (g) & $39.95 \pm 0.09$ & $39.96 \pm 0.02$ & $40.06 \pm 0.12$ & $40.14 \pm 0.05$ & $39.99 \pm 0.09$ & $40.12 \pm 0.17$ \\
\hline Final weight (g) & $162.39 \pm 2.31^{\mathrm{cd}}$ & $173.52 \pm 2.02^{\mathrm{ab}}$ & $178.39 \pm 4.96^{\mathrm{a}}$ & $176.21 \pm 7.84^{\mathrm{a}}$ & $170.43 \pm 3.34^{\mathrm{ab}}$ & $164.01 \pm 2.89^{b}$ \\
\hline Weight gain (\%) & $306.48 \pm 6.21^{\mathrm{c}}$ & $334.18 \pm 5.27^{\mathrm{ab}}$ & $345.36 \pm 6.09^{\mathrm{a}}$ & $338.98 \pm 2.18^{\mathrm{a}}$ & $326.24 \pm 3.47^{\mathrm{ab}}$ & $308.87 \pm 8.60^{\mathrm{bc}}$ \\
\hline Feed conversion ratio & $0.77 \pm 0.01^{\mathrm{ab}}$ & $0.69 \pm 0.01^{\mathrm{bc}}$ & $0.65 \pm 0.03^{c}$ & $0.69 \pm 0.01^{b c}$ & $0.74 \pm 0.08^{\mathrm{ab}}$ & $0.81 \pm 0.05^{\mathrm{a}}$ \\
\hline Protein efficiency ratio & $2.87 \pm 0.04^{\mathrm{cd}}$ & $3.19 \pm 0.05^{\mathrm{ab}}$ & $3.39 \pm 0.14^{\mathrm{a}}$ & $3.18 \pm 0.07^{\mathrm{ab}}$ & $2.99 \pm 0.13^{\mathrm{bc}}$ & $2.71 \pm 0.14^{\mathrm{d}}$ \\
\hline Survival (\%) & $93.71 \pm 1.12$ & $92.86 \pm 4.12$ & $95.48 \pm 2.38$ & $95.24 \pm 4.76$ & $95.71 \pm 4.12$ & $93.33 \pm 4.76$ \\
\hline
\end{tabular}

The values in the same row with different upper letter indicate significant difference $(P<0.05)$. 
Table 5. Whole-body and muscle composition of bullfrog fed with different experimental diets (\% wet-weight basis).

\begin{tabular}{|c|c|c|c|c|c|c|}
\hline & \multicolumn{6}{|c|}{ Methionine levels (\%) } \\
\hline & 0.63 & 1.00 & 1.42 & 1.78 & 2.26 & 2.68 \\
\hline \multicolumn{7}{|l|}{ Whole-body } \\
\hline Moisture & $77.06 \pm 0.54$ & $77.68 \pm 0.49$ & $76.95 \pm 0.78$ & $76.41 \pm 0.37$ & $76.46 \pm 0.52$ & $77.76 \pm 0.77$ \\
\hline Crude protein & $15.12 \pm 0.17$ & $14.99 \pm 0.20$ & $15.38 \pm 0.43$ & $15.48 \pm 0.24$ & $15.45 \pm 0.27$ & $14.96 \pm 0.37$ \\
\hline Crude lipid & $4.32 \pm 0.03^{\mathrm{ab}}$ & $4.01 \pm 0.30^{\mathrm{ab}}$ & $4.18 \pm 0.06^{\mathrm{ab}}$ & $4.46 \pm 0.09^{\mathrm{a}}$ & $4.50 \pm 0.02^{\mathrm{a}}$ & $3.82 \pm 0.04^{\mathrm{b}}$ \\
\hline Crude ash & $2.19 \pm 0.13$ & $2.24 \pm 0.12$ & $2.27 \pm 0.01$ & $2.24 \pm 0.01$ & $2.23 \pm 0.08$ & $2.18 \pm 0.06$ \\
\hline \multicolumn{7}{|l|}{ Muscle } \\
\hline Moisture & $77.56 \pm 0.19$ & $76.36 \pm 0.12$ & $77.01 \pm 0.49$ & $76.92 \pm 0.37$ & $77.07 \pm 0.07$ & $77.23 \pm 0.27$ \\
\hline Crude protein & $19.31 \pm 0.04$ & $20.00 \pm 0.38$ & $19.85 \pm 0.35$ & $19.92 \pm 0.22$ & $19.42 \pm 0.02$ & $19.49 \pm 0.14$ \\
\hline Crude lipid & $0.37 \pm 0.02^{\mathrm{ab}}$ & $0.32 \pm 0.01^{\mathrm{b}}$ & $0.41 \pm 0.02^{\mathrm{a}}$ & $0.39 \pm 0.02^{\mathrm{ab}}$ & $0.34 \pm 0.02^{\mathrm{ab}}$ & $0.34 \pm 0.01^{\mathrm{ab}}$ \\
\hline Crude ash & $1.09 \pm 0.02$ & $1.10 \pm 0.03$ & $1.06 \pm 0.02$ & $1.08 \pm 0.01$ & $1.05 \pm 0.03$ & $1.01 \pm 0.01$ \\
\hline
\end{tabular}

The values in the same row with different upper letter indicate significant difference $(P<0.05)$. 
Table 6. Amino acid composition in muscle of bullfrogs fed with different experimental diets (\% dry-matter basis)

\begin{tabular}{|c|c|c|c|c|c|c|}
\hline \multirow[t]{2}{*}{ Amino acids } & \multicolumn{6}{|c|}{ Methionine levels (\%) } \\
\hline & 0.63 & 1.00 & 1.42 & 1.78 & 2.26 & 2.68 \\
\hline \multicolumn{7}{|l|}{ EAA } \\
\hline Arg & $6.22 \pm 0.13$ & $6.35 \pm 0.12$ & $6.44 \pm 0.15$ & $6.36 \pm 0.13$ & $6.26 \pm 0.05$ & $6.36 \pm 0.16$ \\
\hline His & $2.37 \pm 0.08$ & $2.53 \pm 0.06$ & $2.45 \pm 0.12$ & $2.37 \pm 0.06$ & $2.34 \pm 0.06$ & $2.51 \pm 0.10$ \\
\hline Ile & $3.67 \pm 0.01$ & $3.68 \pm 0.06$ & $3.74 \pm 0.02$ & $3.72 \pm 0.02$ & $3.59 \pm 0.03$ & $3.62 \pm 0.04$ \\
\hline Leu & $7.07 \pm 0.03$ & $7.01 \pm 0.12$ & $7.12 \pm 0.04$ & $7.09 \pm 0.05$ & $6.88 \pm 0.02$ & $6.97 \pm 0.07$ \\
\hline Lys & $8.83 \pm 0.11$ & $8.82 \pm 0.22$ & $9.09 \pm 0.09$ & $9.14 \pm 0.11$ & $8.94 \pm 0.13$ & $8.78 \pm 0.07$ \\
\hline Met & $2.40 \pm 0.02$ & $2.39 \pm 0.07$ & $2.45 \pm 0.03$ & $2.47 \pm 0.01$ & $2.41 \pm 0.01$ & $2.44 \pm 0.02$ \\
\hline Phe & $3.22 \pm 0.06$ & $3.25 \pm 0.04$ & $3.25 \pm 0.04$ & $3.22 \pm 0.07$ & $3.13 \pm 0.02$ & $3.17 \pm 0.05$ \\
\hline Thr & $3.86 \pm 0.04$ & $3.87 \pm 0.07$ & $3.94 \pm 0.04$ & $3.94 \pm 0.03$ & $3.86 \pm 0.02$ & $3.87 \pm 0.05$ \\
\hline Val & $3.69 \pm 0.2$ & $3.71 \pm 0.07$ & $3.79 \pm 0.04$ & $3.78 \pm 0.02$ & $3.70 \pm 0.04$ & $3.68 \pm 0.06$ \\
\hline \multicolumn{7}{|l|}{ NEAA } \\
\hline Ala & $5.00 \pm 0.05$ & $4.97 \pm 0.10$ & $4.99 \pm 0.03$ & $5.02 \pm 0.04$ & $4.99 \pm 0.04$ & $4.89 \pm 0.04$ \\
\hline Asp & $8.93 \pm 0.06$ & $8.78 \pm 0.18$ & $9.07 \pm 0.11$ & $8.97 \pm 0.09$ & $8.88 \pm 0.08$ & $8.87 \pm 0.15$ \\
\hline Cys & $7.57 \pm 0.21$ & $7.12 \pm 0.15$ & $7.54 \pm 0.22$ & $7.50 \pm 0.32$ & $7.40 \pm 0.51$ & $7.54 \pm 0.67$ \\
\hline Glu & $14.52 \pm 0.11$ & $14.31 \pm 0.26$ & $14.43 \pm 0.19$ & $14.55 \pm 0.09$ & $14.14 \pm 0.09$ & $14.32 \pm 0.17$ \\
\hline Gly & $3.91 \pm 0.06$ & $3.87 \pm 0.04$ & $3.91 \pm 0.03$ & $3.94 \pm 0.04$ & $3.89 \pm 0.07$ & $3.8 \pm 0.06$ \\
\hline Pro & $2.89 \pm 0.03$ & $2.86 \pm 0.03$ & $2.93 \pm 0.02$ & $2.94 \pm 0.04$ & $2.93 \pm 0.04$ & $2.93 \pm 0.05$ \\
\hline Ser & $3.56 \pm 0.95$ & $3.60 \pm 0.07$ & $3.69 \pm 0.06$ & $3.70 \pm 0.04$ & $3.66 \pm 0.04$ & $3.69 \pm 0.05$ \\
\hline Tyr & $4.29 \pm 0.03$ & $4.28 \pm 0.06$ & $4.30 \pm 0.05$ & $4.26 \pm 0.07$ & $4.12 \pm 0.01$ & $4.21 \pm 0.05$ \\
\hline
\end{tabular}


Table 7. Metabolite profiles in serum of bullfrogs fed with different experimental diets.

\begin{tabular}{lllllll}
\hline & \multicolumn{5}{c}{ Methionine levels $(\%)$} \\
\cline { 2 - 6 } & 0.63 & 1.00 & 1.42 & 1.78 & 2.26 & 2.68 \\
\hline TG (mmol/L) & $1.22 \pm 0.04^{\mathrm{a}}$ & $1.20 \pm 0.05^{\mathrm{a}}$ & $1.08 \pm 0.05^{\mathrm{ab}}$ & $0.89 \pm 0.08^{\mathrm{b}}$ & $1.02 \pm 0.02^{\mathrm{ab}}$ & $1.26 \pm 0.10^{\mathrm{a}}$ \\
$\mathrm{CHO}(\mathrm{mmol} / \mathrm{L})$ & $1.75 \pm 0.01^{\mathrm{a}}$ & $1.51 \pm 0.32^{\mathrm{ab}}$ & $1.18 \pm 0.12^{\mathrm{abc}}$ & $0.78 \pm 0.13^{\mathrm{c}}$ & $1.22 \pm 0.07^{\mathrm{abc}}$ & $1.52 \pm 0.05^{\mathrm{ab}}$ \\
AST (U/L) & $7.86 \pm 0.10^{\mathrm{a}}$ & $6.80 \pm 0.01^{\mathrm{b}}$ & $4.29 \pm 0.08^{\mathrm{d}}$ & $4.42 \pm 0.13^{\mathrm{d}}$ & $5.59 \pm 0.01^{\mathrm{c}}$ & $5.68 \pm 0.08^{\mathrm{c}}$ \\
ALT (U/L) & $9.62 \pm 0.28^{\mathrm{a}}$ & $4.74 \pm 0.04^{\mathrm{b}}$ & $4.59 \pm 0.15^{\mathrm{bc}}$ & $4.51 \pm 0.02^{\mathrm{bc}}$ & $4.49 \pm 0.06^{\mathrm{bc}}$ & $3.04 \pm 0.02^{\mathrm{d}}$ \\
\hline
\end{tabular}

TG: triglyceride; CHO: cholesterol; AST: aspartate aminotransferase; ALT: alanine aminotransferase.

The values in the same row with different upper letter indicate significant difference $(P<0.05)$. 
Figure 1

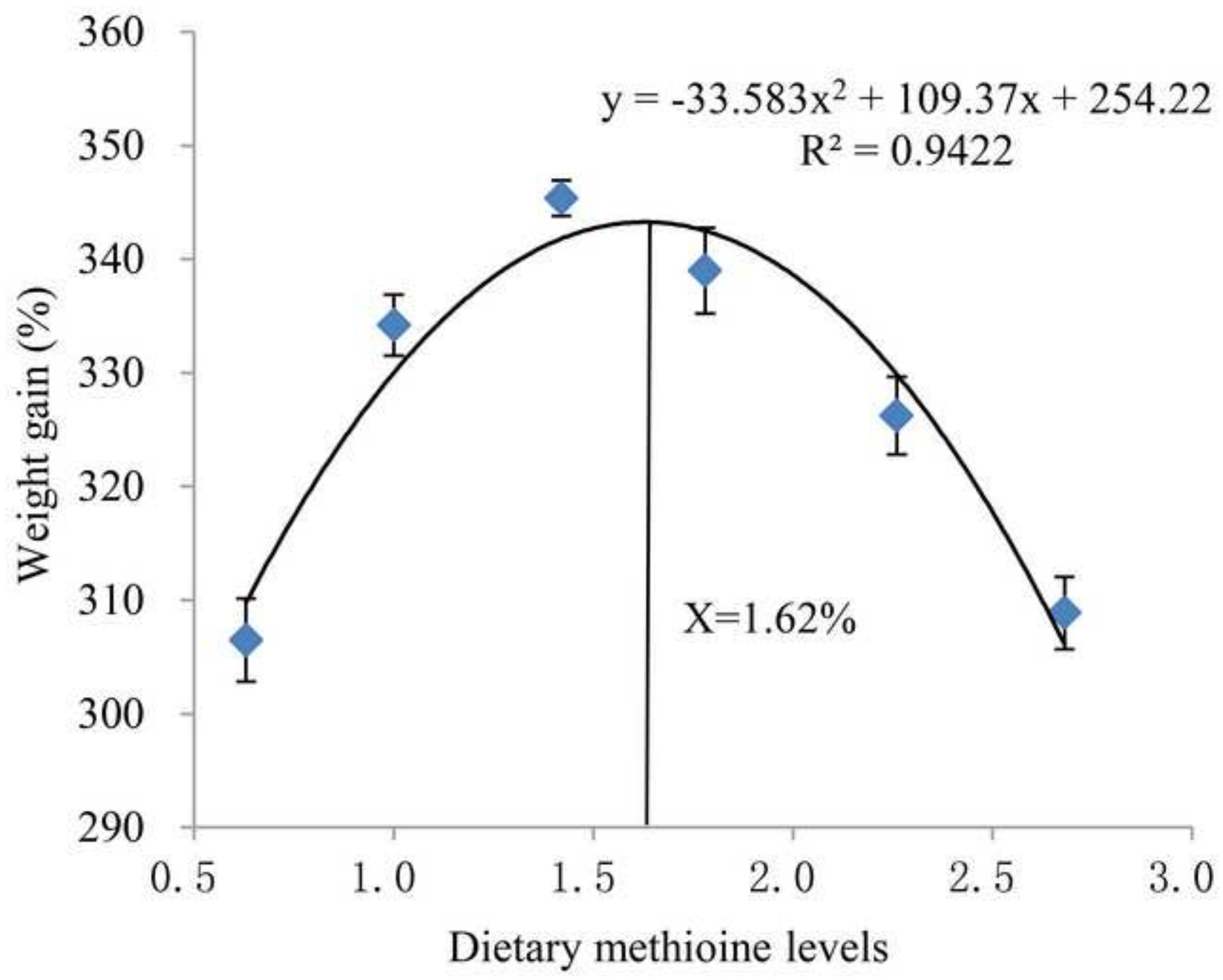




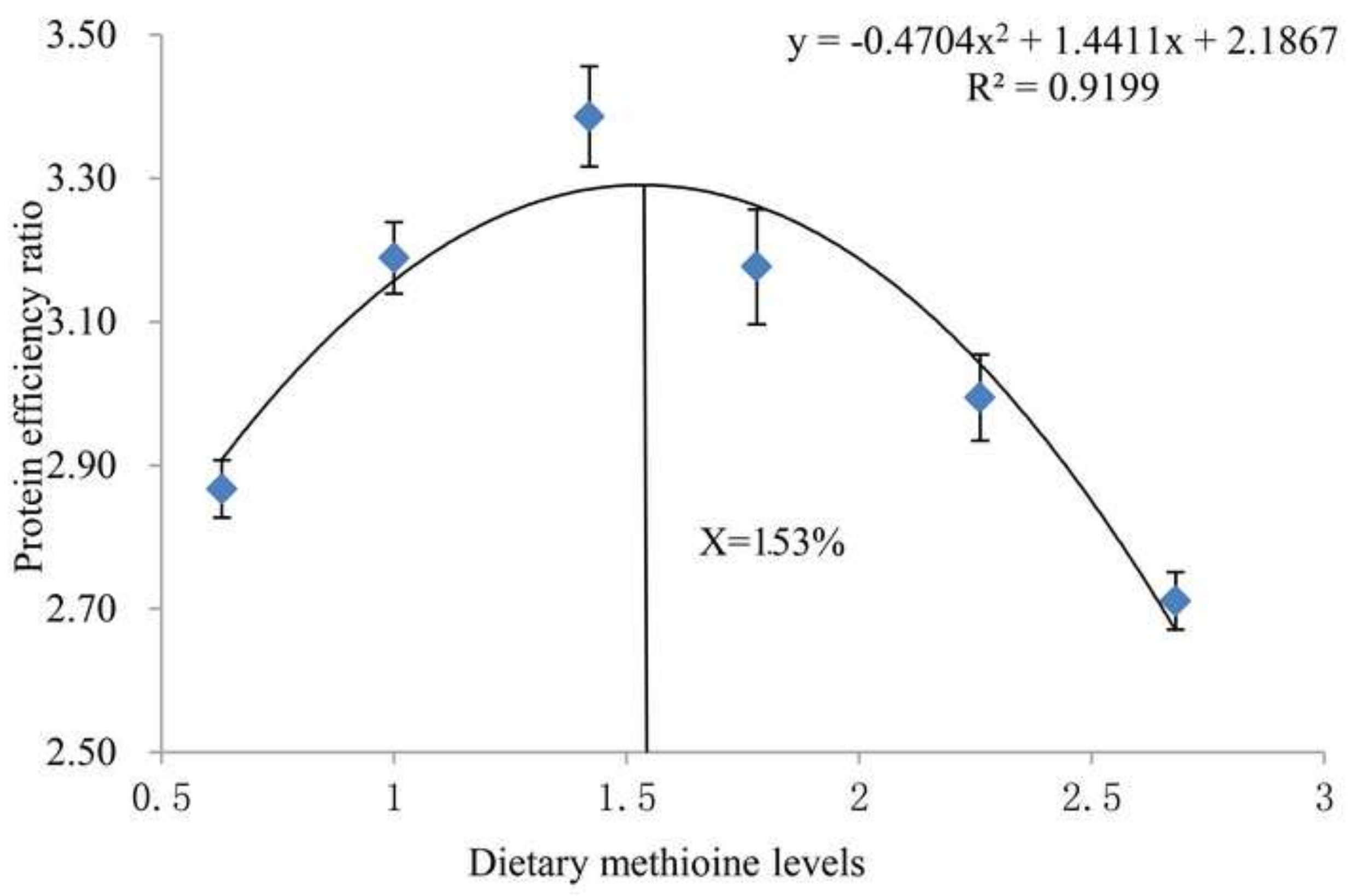


A

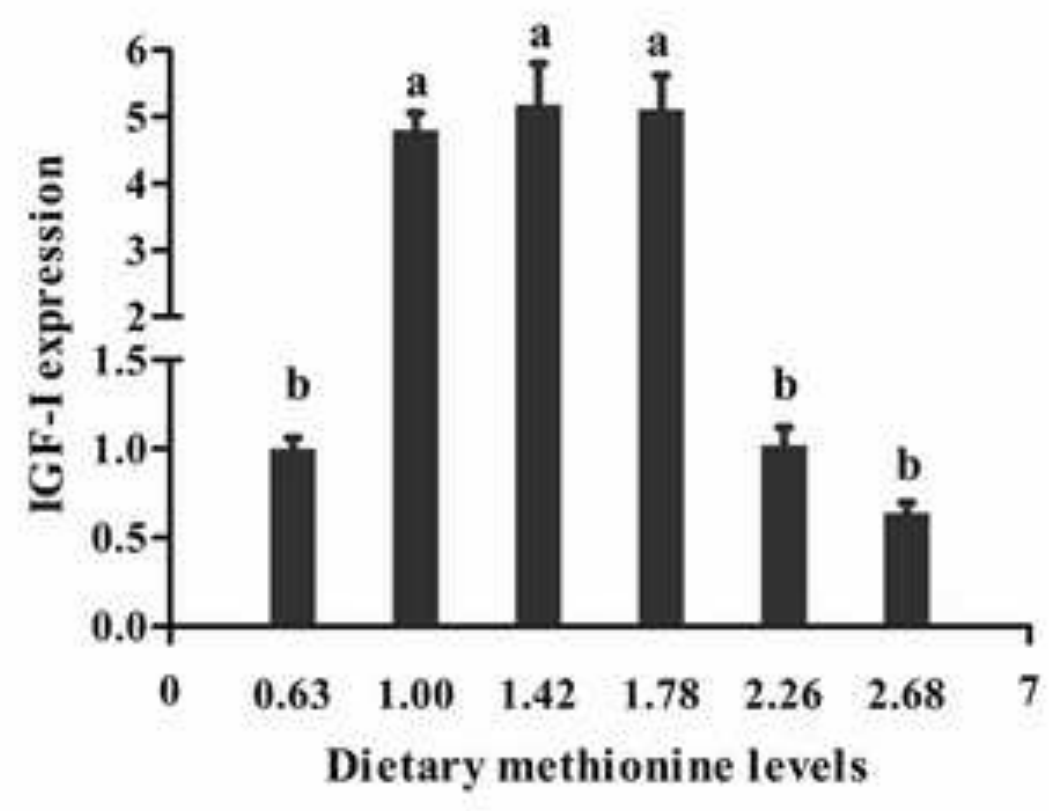

B

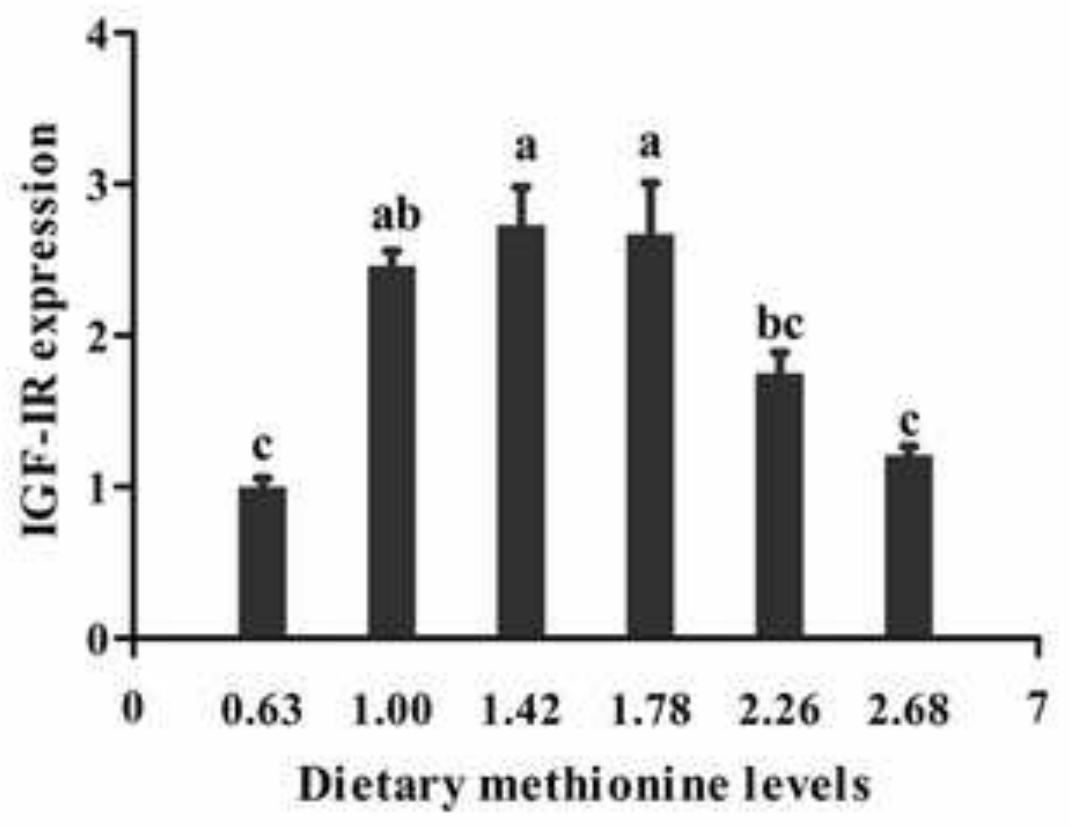

